\title{
○中田孝重・海江田純㢁・中尾善亮・宮崎的 大沢広秀・涱上秀伯（長崎大学耳架㕧喉科）
}

【はじめに】

聴力正常者の蛤電図では $1 \mathrm{kHz} に お い て \mathrm{CM}$ 検出域値は。ほほ純音聴力域值と一致し ており，とくにAPのL-partに相当する部分（50dB以下）で明らかな shift が留めら

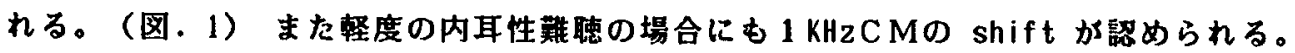

（図．2）ところで後迷路性雖聴においては $1 \mathrm{kHz} \mathrm{CM}$ shift が認められるものと，そ うでないもの（图．3）がある。そこで蝴電图上から後迷路性疾患でありながら内耳性難 䁣のバターンを示す因果関係を検討した。また $1 \mathrm{KHz} \mathrm{CM}$ shift が認められない原因と して遠心性㯖覚ニューロン（OC B）の関与を考光検討した。

その他 viral infection (Mumps) , 白血病 (ALL) の中にも $1 \mathrm{KHz} C \mathrm{C}$ の shift 加認め られない症例があったので比皎梌討した。

【対象および方法】

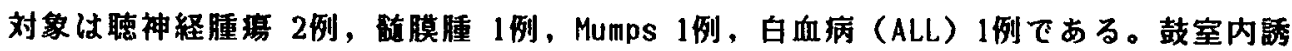
每法により，検查音として，A Pの测定には $4 \mathrm{KHz} 1 \mathrm{cycle} の \mathrm{click}$ を使用し，CMの测 定には short tone burst を用いた。また検查音は検耳前方 $50 \mathrm{~cm} の$ 距離より与えた。

【結果および考察】（表。1）

後迷路性難聴の中には従来から内耳性難聴のパターンを示す例があると言われている。 今回, 後迷路性難聴の病熊を理解するために蜩電図上で，1）A P と純音聴力の域値との gap の有無，2） CMの検出域值（とくに1 kHz），3）1 KHzCMの shift の有無から検 封してみた。内耳性踑聴のバターンには，A P と純音聴力の域值との gap (-)，1 KHa

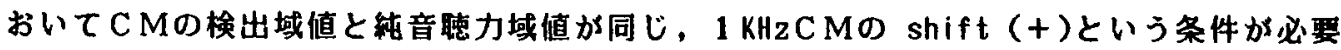
であり，後迷路性蜼聴のバターンには，A P と純音聴力の域值との gap $(+), \mathrm{CM}$ 検

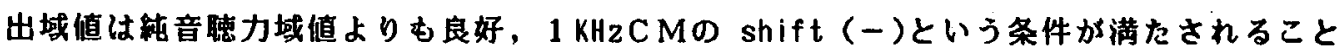
が必要である。また両者が混合したバターンも経過中には認められると考える。

症例 (1) は内耳性蜼聴同样 $1 \mathrm{kHzC}$ Mの shift $(+)$ で, 補充現象 $(+)$ である。これ は腫韵の圧迫による内耳血流障害のため内耳有毛細胞障害をきたしているが，蛤牛遠心路 の障害はないと考えられる。

症例 (2) では $1 \mathrm{KHz} C \mathrm{M} の$ shift（一) 純音聴力は scale out で型的な後迷路性蜼㯖のバターンを示している。内耳有毛册胞

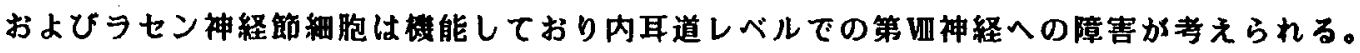

症例 (3),(4) は術後に聴力の改善をみた檤膜腫の例である。術前は症例(2)と同じく $1 \mathrm{KHz}$ CMの shift (ー)で, 後迷路性難聴のバターンを示していたが, 術後は反対㑡と同じ植 音聴力まで改善し症例(1)と同様に $1 \mathrm{kHzC}$ Mの shift (+)で, 内耳性蜼聴のバターンに 变化した。これは腫堭の摘出により第䜣神経への圧迫がなくなり機能が回復したためと责 えられる。

症例 (5) は Mumpsによる難聴で $1 \mathrm{kHzCM}$ Shift（ー）の例である。オージオグラム

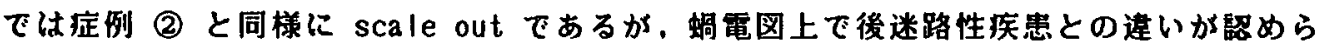


れる。つまり，この例ではAP（no response）と純音聴力の域值（scale out）に gap が認められず，ラセン神経節轭胞レベルでの障害が考えられる。

症例 (6) は白血病（ALL）で難聴をきたした例である。これにはA P と純音聴力の域值 に gap があり後迷路性難聴のパターンを呈しているが，APの域檤は40dBである。これ はラセン神経節〜内耳道における白血病細胞の漫洞, あるいは出血による血腫のため後迷 路性難聴に似た病熊を呈したためと考えられる。

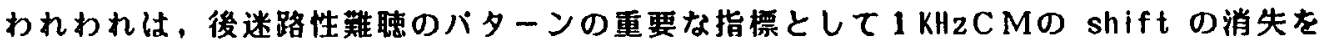
考え，その原因として蛤牛遠心路（ＯＣＢ）に障害をきたしたからではないかと推测した。 $1 \mathrm{KHzCM}$ shift（+)という反応は，聴力正常者や轻度の内耳性難聴でみられる。また 蛤牛の伝播様式として, 刺做音压が低くなるにつれて, 蛤牛での最大振幅の場所が頂回転 側へ移動し，いずれその特徽周波数の場所に落ち着くと考えられるから，そのためにCM の shift が扢るではないかと考えている。従ってCMの shift の有無は，蛤牛の内耳 有毛緗胞を介した周波数分析能を反映していると考えられ, 蛤牛遠心路（ＯCB）か障害 されると，その周波数分析能に变調をきたし CMの shift の消失を招くものと推测され た。

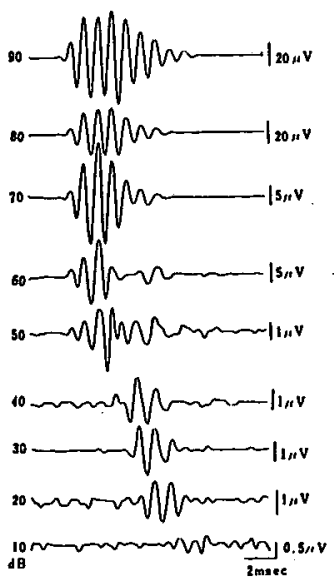

（图.1）踝力正常
$1 \mathrm{KHz} C \mathrm{M}$

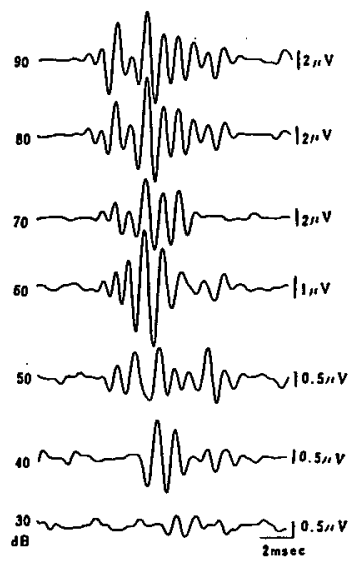

（図. 2）内耳性難聴

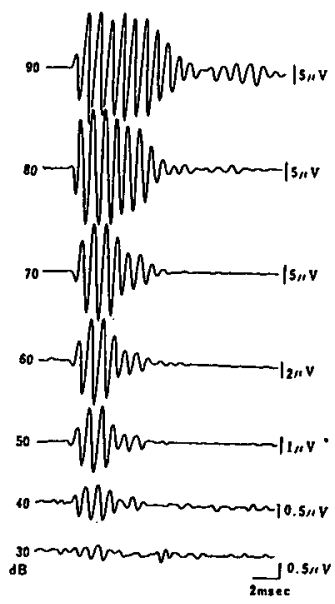

（因，3）後迷路性嚾僡 shift $(-)$

( 表. 1)

\begin{tabular}{|c|c|c|c|c|c|c|c|}
\hline & \multirow{2}{*}{ 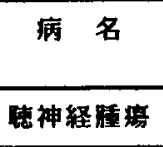 } & \multirow{2}{*}{ 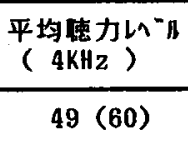 } & \multirow{2}{*}{$\frac{A P \text { 域値 }}{50 \mathrm{~dB}}$} & \multicolumn{2}{|c|}{$\begin{array}{c}\mathrm{C} M \text { 域犆 } \\
\mathrm{IKHz} \quad 4 \mathrm{KHz}\end{array}$} & \multirow{2}{*}{$\frac{1 \mathrm{KHzCM} \text { shift }}{+}$} \\
\hline (1) & $47 \hat{8}$ & & & & 40 & 70 & \\
\hline (2) & 409 & 㯖神経腫嫫 & Scale out & 10 & 20 & 50 & - \\
\hline (3) & 469 & 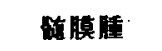 & $65(50)$ & 10 & 30 & 40 & - \\
\hline (4) & 同上 & 同上(楺後) & $29(30)$ & 10 & 30 & 40 & + \\
\hline (5) & $65 \delta$ & Mumps & Scale out & $(-)$ & 30 & 50 & - \\
\hline (6) & $18 \delta$ & 白血病 & $63(65)$ & 40 & 30 & 20 & - \\
\hline
\end{tabular}

